\title{
An Exploratory Study of Typical and Traditional Culinary Arts in Surakarta and Semarang as Cultural Heritage to Support Indonesian Tourism Industry
}

\author{
Wienny Ardriyati ${ }^{1} \&$ Julius Arya Wiwaha ${ }^{2}$ \\ ${ }^{1}$ English Literature, Stikubank University, Semarang, Indonesia \\ ${ }^{2}$ Department of Tourism, Stikubank University, Semarang, Indonesia \\ Correspondence: Wienny Ardriyati, English Literature, Stikubank University, Semarang, Indonesia. E-mail: \\ wien_ardri@yahoo.com
}

Received: December 30, 2015 Accepted: January 17, 2016 Online Published: January 25, 2016

doi:10.5539/ach.v8n1p132

URL: http://dx.doi.org/10.5539/ach.v8n1p132

\begin{abstract}
As a three-year-project funded by the Government of Indonesia in support of tourism industry, the current study explored the existence of tradional culinary arts of Surakarta and Semarang, Central Java, Indonesia in an attempt to promote Indonesian tourism industry. A variety of traditional snacks from the two cities were identified to find out the similarities and differences in terms of exclusiveness and flavors. As a qualitative and descriptive research, the data were collected through observation on the types of traditional snacks, and interviews with the vendors with respect to the process of production. The findings showed that Surakarta is rich in traditional snacks, such as Sosis Solo, Jadah Blondo, Intip Goreng, Rambak, and various kinds of Lenjongan. In Semarang, on the other hand, there are Ganjel Ril, Winbgko Babat, Kue Senteling, Wedang Tahu, Lumpia and one type of Lenjongan-therefore Lenjongan can be assumed is the only similar food in the two cities. The snacks from the two cities have distinctive features of flavors that deserve both domestic and international recognition. Therefore these types of snacks can be tourism icons to attrack national and international tourists to visit both cities. In conclusion, the typical traditional culinary arts should be preserved and maintained to support Indonesian tourism industry.
\end{abstract}

Key words: exploratory, traditional culinary, surakarta, semarang

\section{Introduction}

\subsection{Background}

Each city in Central Java, Indonesia has particular types of culinary arts, which can be an identity of the place, the people and the culture. Semarang and Surakarta are two significant cities; the former is the Capital City of Central Java and latter famous for its cultural heritages as Central Java identity. Therefore the two cities become the objects of a three year research project featuring their culinary arts by identifying, describing the typical and traditional snacks in an attempt to provide formal documentation.

It is necessary to document the typical and traditional snacks so as for them not to disappear due to the modern snacks that may replace the traditional ones. Alongside with the development, the existence and variety of traditional snacks are likely to develop. The worst possibility is that the traditional snacks become slowly (if not entirely) forgotten by the people because of so new types of food coming from other countries. Yet, local people seem to maintain their pride of the traditional culinary arts as part of the attributes of Indonesia that needs to be preserved in support of tourism industry. One of the efforts to preserve this highly valued culinary heritage is to explore, identify and document them in proper classifications and functions. Therefore the current study was oriented to the exploration of the traditional snacks as manifestation of the culinary arts in Surakarta and Semarang.

\subsection{Objectives of the Study}

Based on the above background, the current study was, in general, aimed at exploring the existence of traditional culinary arts in Semarang and Surakarta manifested in the typical snacks in the two cities in terms of similarities and differences. In particular, however, the study may also function as a preliminary undertaking for the preservation of the traditional culinary arts in support of Indonesian tourism industry. Furthermore, the younger 
generation can be of pride that they have culinary traditions preserved as cultural heritage. Finally, documentation of the culinary heritage can function as the barrier over the claim by other over the origin of the foods in question

\subsection{Literature Review}

A traditional snack is actually a unique manifestation of culture. Unfortunately, it is often forgotten in spite of its potential to attract to foreign tourists. So simple as they are, the traditional snacks are, in fact, inseparable parts of the Indonesia's traditional culinary arts that need to be maintained and preserved, so as to promote Indonesian tourism (Shelly, 2012). It is commonly known that international tourists prefer to eat local foods with traditional flavors which cannot be found in their countries back home. It is therefore important to create an inventory of local, even traditional foods in formal documentation

Furthermore, Indonesian tourism industry has been basically developed on the basis of uniqueness in order to attract international tourists in the spirit of "Go Green and Back to Nature". However, the use of informationa technology in tourism industry is unavoidable. Dawn and Ferdiana (2012), for example, reiterated the use of IT for a fast delivery and dissemination of information to users. Even information on culinary tourism in Yogyakarta (one of the famous tourist destinations) can now be obtained through a mobile application. This, of course, includes the introduction of traditional foods in trourism industry (Pansiri \& Corurvisanos, 2011).

\section{Method}

\subsection{Nature of the Study}

This research is concerned with the exploration of the cultural heritage manifested in traditional snacks as the culinary arts of Central Java. In other words the current study is explorative in nature aimed at finding out the typical and traditional snacks in Surakarta and Semarang. The subjects of the study consisted of five individuals as snack producers in their home industries, and seventeen vendors (retailers) selling the snacks at the traditional markets

\subsection{Research Procedures}

Observation was performed to explore (make an inventory of) the types of traditional snacks in both Surakarta and Semarang, especially focusing on the traditional markets. Then, interviews involving both the vendors and producers were conducted in order to get thorough pictures of types of snacks under investigation. The vendors were interviewed regarding three issues (1) the most favorite snack, (2) types of customers, (3) reasons for purchase of snacks. Meanwhile, the producers were interviewed with respect to the process of production.

Based on the data, profiles of typical traditional snacks were made in pictures with complete description on each type of snacks with respect to the production process from the raw ingredients to the finished products (snacks ready for sale),

\subsection{Data Analysis and Presentation}

On completion of data collection, the snacks were classified into (1) types of similar ingredients (2) levels of popularity (3) places of sales, (4) similarities of snacks (from the two cities) used in "Tedak Siti" ceremony, that is a ceremony to celebrate the first time a baby touches the ground with his or her legs to start walking. A picture of each snack is herewith displayed along with its description.

\section{Findings and Discussion}

\subsection{Traditional Culinary Arts of Surakarta}

Surakarta, located in the southern coast of Java, is famous as a city of its Javanese traditions, the Royal City of Solo or Surakarta is famous for its monarchy called Surakarta Hadiningrat with the King crowned as Paku Buana XIII. The King is thereby recognized, in Indonesia, as a strong upholder of the Javanese culture. Even, Surakarta is famous for its Javanese cultural heritage. Thus, the standard of both Javanese language and culture is pertinent to the existence of Surakarta language and culture. Below is a map showing Surakarta (Solo) and Semarang; both located in Central Java, Indonesia: 


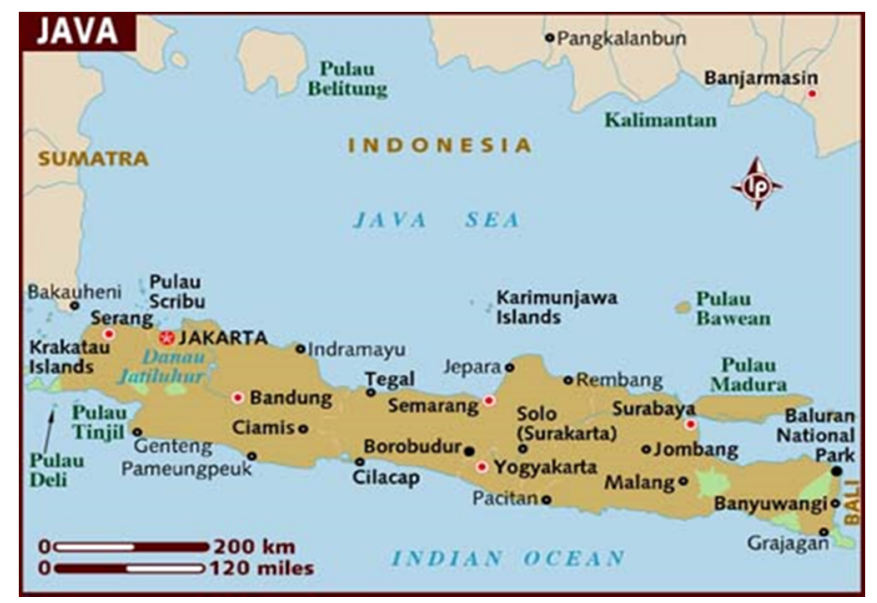

Map of Central Java, Indonesia

Most importantly, however, Surakarta is famous not only for the Javanese culture but also traditional snacks. The typical and traditional culinary assets of Surakarta that were identified and should therefore be preserved include:

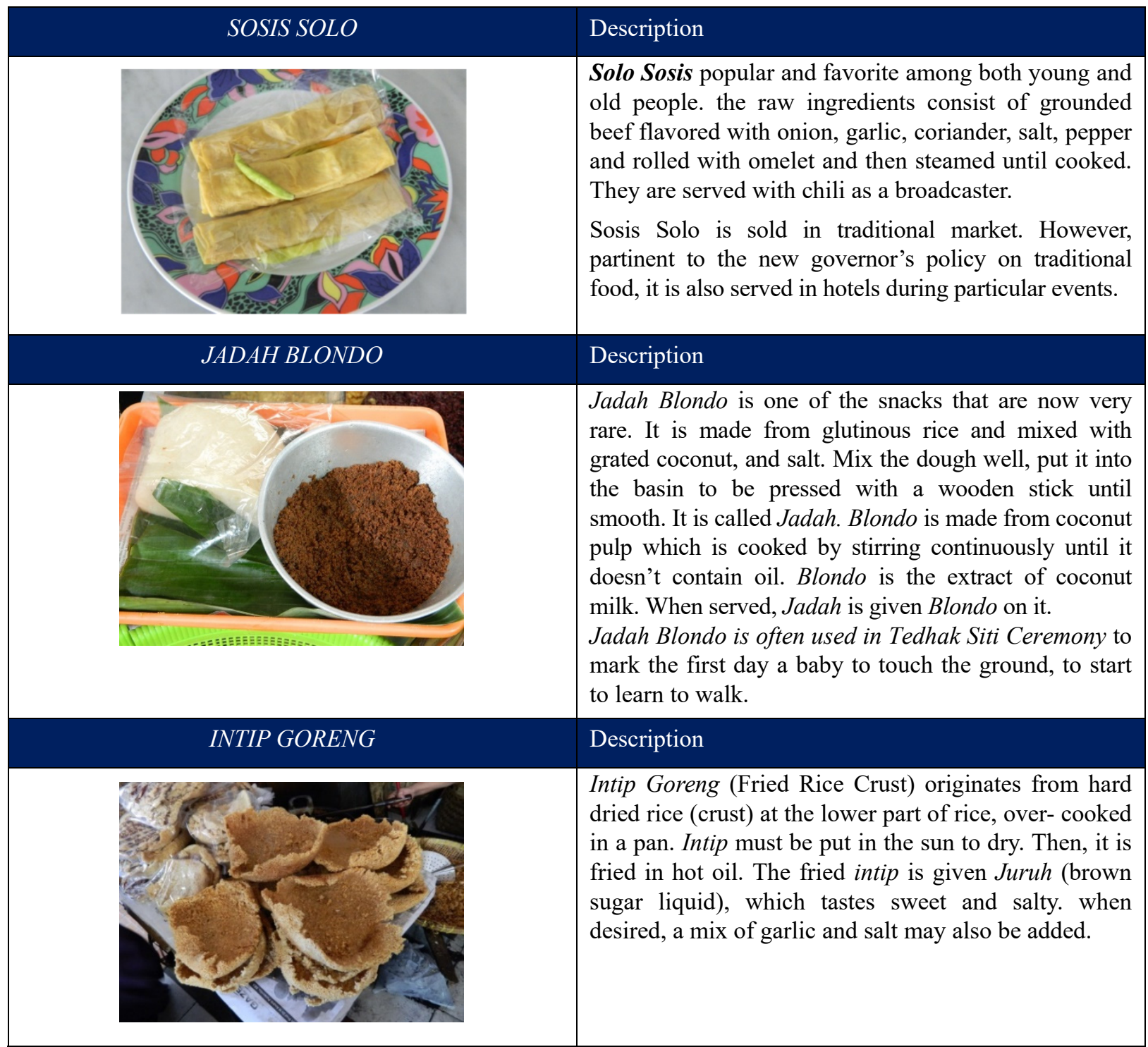




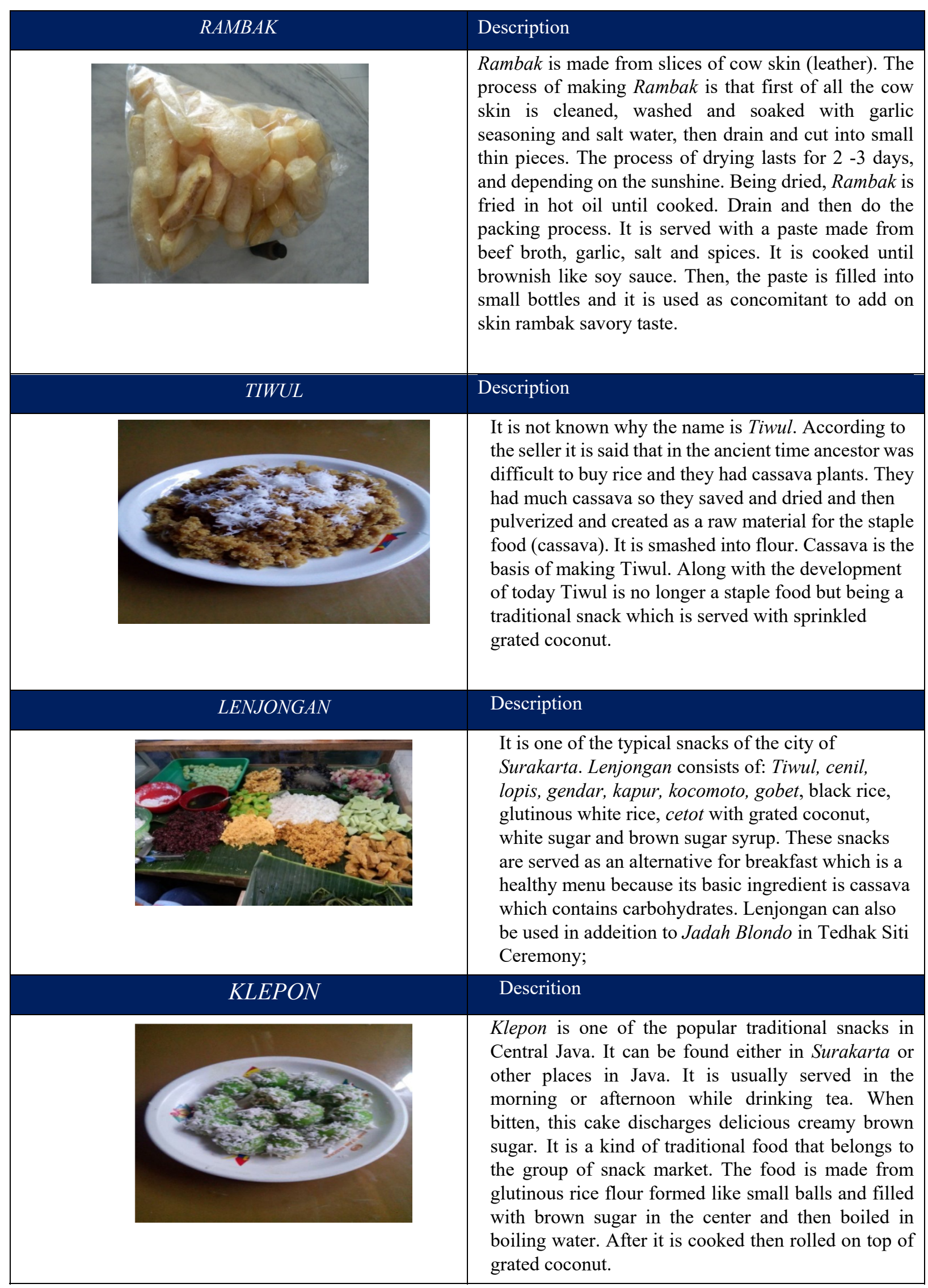




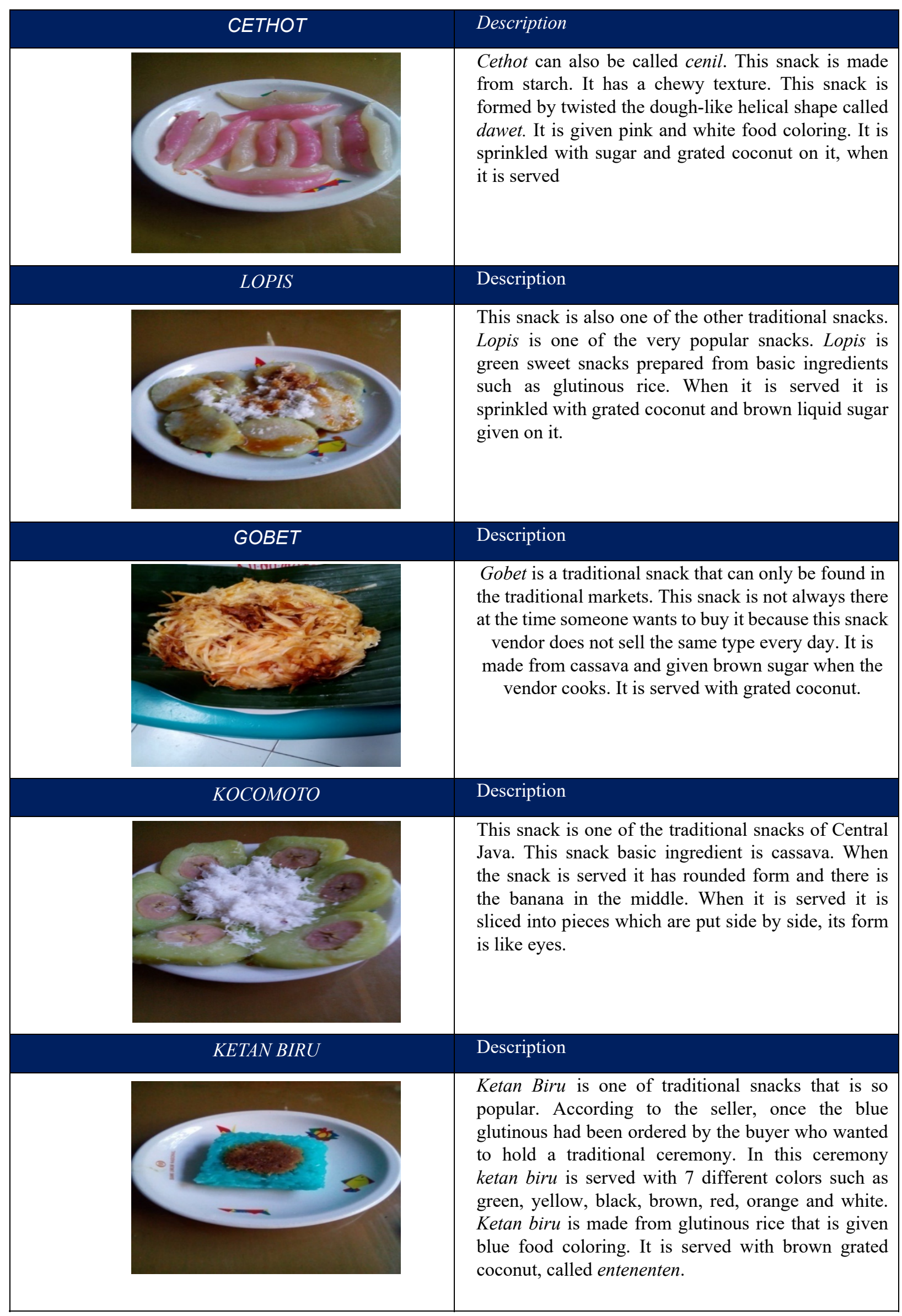




\subsection{Traditional Culinary Arts of Semarang.}

Due to the constraints of space, the following snacks of typical products of Semarang are described without their corresponding images. Semarang, located in the northern coast of Java, is the capital of Central Java. It is the business center with its international airport and harbor.

Several traditional snacks in Semarang deserve to be promoted to the wider community through cultural and business activities that are regularly held, as Semarang has become one of the trading venues and services in the northern coast of Java, Indonesia. Artifacts and buildings as markers of the colonial Dutch can also still be found

The typical traditional snacks can be maintained up till now, as the following:

\section{(1) Ganjel Ril}

Ganjel Ril is a typical snack of Semarang. Ganjel ril is less well known than other snacks because the texture is not soft. The texture is slightly chewy. Ganjel ril has a box-shaped and sprinkled with brown sesame, dense chewy texture and combined with the scent of chocolate and cinnamon. Because the texture is chewy and dense if one eats two pieces, it can cause the stomach full. This snack contains a lot of fiber and makes full for breakfast, and good for digestion. It is made from wheat, brown sugar, sesame and fennel.

\section{(2) Wingko Babat}

Wingko babat is a traditional snack that can be found in Semarang. It is Semarang typical snack and very famous as souvenirs. Wingko itself is a snack made from glutinous rice and dough burned coconut. It is tasty and can last for 2-5 days, though made without preservatives. Now it is available with a variety of flavors, ranging from young coconut, jackfruit, durian until chocolate tastes

\section{(3) Kue Senteling}

Kue senteling is very attractive with pink and light yellow color. This traditional snack is made from grated cassava. The grated cassava is mixed with a little salt and vanila. After it becomes dough, it is divided into two; one part is given food coloring and the other is still as natural as the color of the grated cassava. After that both dough are steamed and finally they are cut into pieces. These snacks are served with grated coconut on it

\section{(4) Wedang Tahu}

It is one of the typical culinary serving of Semarang and people can often find in the traditional markets. The basic ingredient is soybeans which are soaked for about 6 hours. Later it is refined by means of milled, filtered with a cloth until it becomes dough like jelly / pudding. This drink is served with boiled ginger water, and it could keep warm for one who drinks it during the rainy seasons.

\section{(5) Lumpia}

Semarang is famous for Lumpia. It is also called as Lumpia city. It is the other typical snack of Semarang. It is a kind of rollade containing bamboo shoots, eggs and chicken or shrimps. The bamboo shoot is cut into thin long slices. Then it is cooked until the bamboo shoot becomes soft. After that fry garlic and put shrimps and other flavourings, put the cut bamboo shoot, give eggs and finally mix all. Take a piece of spring roll put some cooked bamboo shoots then roll it. Do all until all finish. This snack can be steamed or fried when it is served.

\section{The similarities and differences of traditional snacks in Surakarta and Semarang}

One difference of the traditional snacks is called Lenjongan. The vendor in Surakarta sells Lenjongan (Conssiting of several snacks) and all mixed together and wrapped in a banana leaf. Meanwhile in Semarang such Lenjongan snack does not have a name. Normally people in Semarang itemize the snacks' names inside the "Lenjongan" as Surakarta's terms

The following are seven typical traditional snacks of Semarang that are similarly found in Surakarta:

(1) Ketan Biru is one of traditional snacks that are very popular.Its bacis ingredient is gulinous rice and given blue food colouring. It is served with grated coconut which is mixd with liquid brown sugar.

(2) Kue Klepon is one of the traditional snacks that is popular as snacks in Indonesia as well as in Semarang. Klepon which is accompanied with a cup of tea is usually served in the morning or afternoon. The ingredients are glutinous rice, pandan leaves, grated coconut, and salt.

(3) Kocomoto's main ingredient is cassava. This snack has a round shape and a slice of a banana in the centre. It looks like glasses when it is put side by side. Every hawker makes different colour to sell kocomoto". The green ones use natural colour that is from pandan leaves. The pink ones use food colouring. 
(4) Lopis' main ingredient is glutinous rice. This snack is also one of the other traditional snacks. Its name is odd. This snack based ingredients are from glutinous rice and coconut.

(5) Gobet is one of traditional snacks that can only be found in the traditional markets. This snack is not always there when someone wants to buy it because the seller of this snack every day provides snacks differently. It is made from cassava.

(6) Tiwul is unknown why it is called "Tiwul". Cassava is the basis ingredient for Tiwul. Along with the development of today "Tiwul" is no longer a staple food but being a traditional snack. It is sprinkled with grated coconut when it is served.

(7) Cethot sometimes has different name "Cenil". The main stuff is starch, sugar and when it is served it is given grated coconut.

Most importantly, the seven types of traditional culinary are mostly made from the stuff (ingredients) such as cassava, starch, glutinous rice, brown sugar and coconut. In each city or region the vendor can make variation both in shape and color.

\section{Conclusion}

Much has been discussed with respect to the traditional foods (snacks) in the two cities: Surakarta and Semarang. The main point is that it is important to preserve such snacks in order to attract foreign and domestic tourists. However, it is not without any problems; most young people do not like having these kinds of foods as they think that such foods are for the lower class people. Therefore the producers are challenged to make more varieties of foods in terms of shapes and colors, maintaining the same ingredients.

It is therefore recommended that the local government reinforce its policy that star hotels are to serve these traditional foods. Corporate meetings are also suggested to make us of these foods as snacks during the coffee break. With the spirit of eco-and back to nature tourism industry, it is high time that traditional culinary heritage were introduced and served hand in hand with the modern 'imported' foods.

\section{Acknowledgments}

Thanks and gratitudes shall go to Directorate Generale of Higher Ecudation, Misnistry of Research -Technology, and Higher Education for the three-year reseach grant with which the current study could be conducted. Secondly, the Head of Research and Community Service Board, including the Dean of Faculty of Language and Cultural Studies for the administrative facilities are also higly appreciated.

\section{References}

Anonymous. (n.d.). Tentang definisi Food. Retrieved: April 15, 2015 from http://www.thefreedictionary.com/ defend

Anonymous. (n.d.). Tentang Surakarta. Retrieved January 18, 2015 from http://id.wikipedia.org/wiki/ Kota_Surakarta

Anonymous. (1996). In Eliazer, Bahruddin, Aziz, 1(1). Art Nouveau, 2013.

Ardriyati, W., Wiwaha, J. A., \& Hartono, B. (2014). Pelestarian Jajanan Tradisional Jawa Tengah sebagai Warisan Budaya Kuliner dengan Multimedia. Hibah Penelitian Nomor: 026/K6/KL/PENELITIAN/2014

Bertha Idelia, S. (2012) Perancangan Buku Visual Jajanan Tradisional Dalam Prosesi Adat Jawa Timur Guna Mendukung Branding "Forgrt The Rest, Come to The Best" Oleh Dinas Kebudayaan dan Pariwisata Jatim. Tugas Akhir Desain Komunikasi Visual, Jurusan Desain Produk Industri, Institut Teknologi Sepuluh Nopember Surabaya.

Bingen, J., Sage, J., \& Sirieix, L. (2011). Consumer Coping Strategies: a Study of Consumers Committed to Eating Local. International Journal of Consumer Studies, 35, 410-419.

Eden Black, R. (2005). The Porta Palazzo Farmers' Market: Local Food, Regulations and Changing traditions. Journal Anthropology of Food, 1-11.

Hidayat, N. F., \& Ferdiana, R. (2012). The Development of Mobile Client Application in Yogyakarta Tourism and Culinary Information System Based on Social Media Integration. Development, 3(10), 71-75.

Grasseni, C. (2011). Re-inventing food: Alpine cheese in the age of global heritage. Anthropology of food, (8), $1-11$.

Karim, M. S. A., Chua, B. L., \& Salleh, H. (2009). Malaysia as a culinary tourism destination: International tourists' perspective. Journal of Tourism, Hospitality \& Culinary Arts, 1(33), 63-78. 
Pansiri, J., \& Courvisanos, J. (2011). Strategic Alliances and Technology in Tourism. Journal of Tourism, Hospitality \& Culinary Arts, 3(1), 25-47.

Soekarto, S. T. (1990). Dasar-dasar Pengawasa dan Standarisasi Mutu Pangan. PAU- Pangan dan Gizi Bogor: IPB Bogor

Eliazer, S. L., Bahruddin, M., \& Aziz, A. (1978). Pembuatan Buku Makanan Tradisional Surabaya Sebagai Upaya Pelestarian Produk Lokal. Jurnal Ilmu danTeknologi Hasil Ternak, 1(1), 24-34.

\section{Copyrights}

Copyright for this article is retained by the author(s), with first publication rights granted to the journal.

This is an open-access article distributed under the terms and conditions of the Creative Commons Attribution license (http://creativecommons.org/licenses/by/3.0/). 